\title{
Geoelectrical Evaluation Of The Variation In The Spatial Distribution Of Aquifers In The Basement Complex - A Case Study Of Laduga Community, Kaduna State, North Central, Nigeria.
}

\author{
Omotayo Kayode Ebenezer ${ }^{1}$ \\ Eduvie Obada Martins ${ }^{1}$ \\ ${ }^{I}$ National Water Resources Institute, Kaduna,Nigeria
}

\begin{abstract}
Absract: To investigate the variation in the spatial distribution of aquifers in the Basement Complex, a total of 12 Vertical Electrical Soundings (VES) were undertaken in the Study Area. The field work was followed by VES Interpretation using IPI2Win electrical resistivity interpretation software, which involves the creation of VES curves, pseudo and resistivity sections. The study revealed considerable variability in the distribution, extent, type, thickness, water content and resistivity of the aquifers in the area. Also the high groundwater potential points in the area have been delineated.
\end{abstract}

Keywords: Aquifers, Vertical Electrical Sounding (VES), Laduga, Electrical resistivity, Groundwater.

\subsection{Statement of the Problem}

\section{Introduction}

Water is a vital necessity for the survival of every living thing. Groundwater is commonly understood to mean water occupying all the voids within geologic stratum. This saturated zone is distinguished from unsaturated zone since its voids are filled with water and air. Water contained in the saturated zones is important for engineering works, geologic studies, and water supply developments (Afuwai et al, 2011, Afuwai, 2013). Groundwater development is relatively cheap and therefore considered a viable option or supplement to the expensive earth and concrete dam systems of surface water supply, where groundwater potential is high (Ademilua et al, 2014). The aquifer is any mass of permeable rock material from which significant amount of water can be recovered. Aquifers differ in properties because these properties are function of rock types constituting them. Different lithologic materials constitute the basement and sedimentary aquifers. In basement terrain, aquifers are fractured rocks and weathered in-situ materials, while the sedimentary aquifers consist of sand and sandstones (Mogaji et al, 2011).

Groundwater occurrence in a Precambrian Basement terrain is hosted within zones of weathering and fracturing which often are not continuous in vertical and lateral extent (Jeff, 2006). Communities located on Basement Complex terrains commonly have problems of potable groundwater supply due to the crystalline nature of the underlying rocks which lack primary porosity. Groundwater storage capacity in those areas is dependent on depth of weathering and intensity of fracturing of the underlying rocks. For Basement Complex rocks to become good aquifers, they must be highly fractured and/or deeply weathered. Thickness of the weathered overburden and fracture zone determines the nature and intensity of hydrodynamic activities within the usually-discrete bodies of aquifers in the terrain. There is a steady rise in the demand for groundwater in most hard rock areas most of which cannot boast of any constant surface source of water supply (Adanu, 1994). The aquifers of the Basement Complex rocks are the regolith and the fractures in the fresh bedrock which are known to be interconnected at depth (Mohammed, 1984; Alagbe, 1987; Adanu, 1989; Umar and Kehinde, 1994; Emmanuel et al 2011; Ismail and Yola, 2012) Groundwater distribution in Basement Complex areas varies from place to place due to the localized nature of basement aquifers (Salphathy and Kanugo, 1976). The spatial variation of the aquifer parameters such as porosity, permeability, transmissivity and conductivity can be attributed to, among other causes, tectonic set-up and degree of weathering of near-surface rocks (Barker et al, 2001). The failure rate in most groundwater projects recorded in Basement Complex has informed the general acceptance of a geophysical survey as a compulsory prerequisite to any successful water well drilling project (Dan Hassan, 1999). Therefore, mapping and characterization of aquifer types and their spatial distribution will enhance the groundwater development in the area of study. The discontinuous nature of the basement aquifer systems makes detailed knowledge and application of the geological, hydrogeological and geophysical investigations inevitable (Anudu et al, 2008). The fractured zones usually occur at deep depths and may have large accumulation of potable water that is protected from pollution while the weathered zones which are usually at shallow depths contain smaller quantity of groundwater. This shallow depth of occurrence commonly 
allow for easy pollution of groundwater in the weathered overburden. The potable water in the deep- seated fractured zone can only be reached with boreholes which are usually expensive and out of reach of most households. In the absence of reliable public water supply, most households rely on hand-dug wells which tap their water from the shallow water table within the weathered overburden. Pollution in this type of aquifers occur both in time and space. Thus there is need for continuous study of groundwater in weathered overburden to understand the hydrodynamics within the subsurface system and to determine the saturated thickness of this shallow aquifer within the overburden (Asiwaju et al, 2013). Water is essential to people and the largest available source of fresh water lies underground. Increased demands for water have stimulated development of underground water resources. As a result, techniques for investigating the occurrence and movement of groundwater have been improved, better equipment for extracting groundwater has been developed, and concepts of resource management have been established.

This study therefore aims at assessing the geoelectric characteristics of the aquiferous units and their implication on groundwater potential of the area with attention on the delineation of the fracture system, overburden thickness and lithologic variation across the terrain.

\subsection{Location and Physiography}

The area of study is in the Laduga community located in Kajuru and Zango Kataf LGAs which share borders with Kauru LGA of Kaduna state (Figure 1). The Study Area comprises Marjire, Tiggirde, Tudun Labi, Yolde Dorobe, Wuro Dalle and Tilde Bayero Communities (Figure2). The location, coordinates and elevation of each VES point are given in table 1 below:

Table 1 Showing the Location, the Coordinates and Elevations of the VES points

\begin{tabular}{|c|c|c|c|}
\hline VES & Community & Coordinates & Elevation (m) \\
\hline 1 & $\begin{array}{l}\text { Marjire ( Marjire Normadic Pry. } \\
\text { Sch) }\end{array}$ & $\begin{array}{l}\mathrm{N} 10.18828^{\circ} \\
\mathrm{E} 008.14360^{\circ}\end{array}$ & 724 \\
\hline 2 & Marjire ( Marjire Mosque) & $\begin{array}{l}\mathrm{N} 10.18864^{\circ} \\
\text { E008.34213 }\end{array}$ & 739 \\
\hline 3 & Tiggirde & $\begin{array}{l}\text { N10.13068 } \\
\text { E008.09803 }\end{array}$ & 729 \\
\hline 4 & Tiggirde & $\begin{array}{l}\mathrm{N} 10.13048^{\circ} \\
\text { E008.09819 }\end{array}$ & 729 \\
\hline 5 & Tudun Labi & $\begin{array}{l}\mathrm{N} 10.18233^{\circ} \\
\mathrm{E} 008.04672^{\circ}\end{array}$ & 712 \\
\hline 6 & Tudun Labi & $\begin{array}{l}\mathrm{N} 10.18271^{\circ} \\
\mathrm{E} 008.04705^{\circ}\end{array}$ & 720 \\
\hline 7 & Yolde Dorobe & $\begin{array}{l}\mathrm{N} 10.24330^{\circ} \\
\mathrm{E} 008.04705\end{array}$ & 762 \\
\hline 8 & Yolde Dorobe & $\begin{array}{l}\mathrm{N} 10.182081^{\circ} \\
\mathrm{E} 008.04705^{\circ}\end{array}$ & 760 \\
\hline 9 & Wuro Dalle & $\begin{array}{l}\mathrm{N} 10.188316^{0} \\
\text { E008.05122 }\end{array}$ & 750 \\
\hline 10 & Wuro Dalle & $\begin{array}{l}\text { N10.182084 } \\
\text { E008.05321 }\end{array}$ & 750 \\
\hline 11 & Tilde Bayero & $\begin{array}{l}\mathrm{N} 10.21345^{0} \\
\mathrm{E} 008.08321^{0}\end{array}$ & 737 \\
\hline 12 & Tilde Bayero & $\begin{array}{l}\mathrm{N} 10.21340^{0} \\
\mathrm{E} 008.08342^{0}\end{array}$ & 737 \\
\hline
\end{tabular}

The area is relatively flat with few and isolated outcrops. Map showing the location of study area with the VES points are shown in Figure 2.

\subsection{Climate and Vegetation}

The area of study lies within the tropical Savanna climate with distinct dry and wet seasons. The dry season occurs between October and April. There is a severe harmattan in December and January. This is the period when the north-east Trade winds begin to blow southwards into the country from the Sahara belt. At this period, it is generally cooler than normal and less humid, and visibility at certain times is restricted as a result of airborne dust. Vegetation in the area is of typical Sudan Savannah, characterized by sparse shrub and interrupted by large isolated trees. There is more continuous cover of grasses. Mean annual evaporation for the area ranges between $1110-1280 \mathrm{~mm}$.

\subsection{Basic Principles}

Electrical Resistivity methods directly gauge the bulk electrical resistance of the ground by measuring spatially varying voltages induced by the passage of an electrical current between electrodes implanted at the 
surface of the ground (Telford et al, 1990). Since most rocks and soils are practical insulators, resistivity of rocks and soils is determined by the amount of conducting mineral constituents and mineralized water in the pores and interstices. The later condition is by far the dominant factor and in fact most rock and soil conduct electric current only because of the contained water. (Kolert, 1969) The most common electrical resistivity methods are Schlumberger, Wenner, and Dipole dipole methods (Telford et al, 1990). The quantity of interest in electrical resistivity survey is the transfer impedance $\mathrm{Z}$, where $\mathrm{Z}=\mathrm{V} / \mathrm{I}$ (i.e $\mathrm{Z}$ has a dimension of $\mathrm{R}$ ). (Keary and Brooks, 1984). In D.C sounding, $Z$ becomes $R$, the transfer resistance and has the dimension of ohms. $R$ is proportional to the apparent resistivity of the medium.

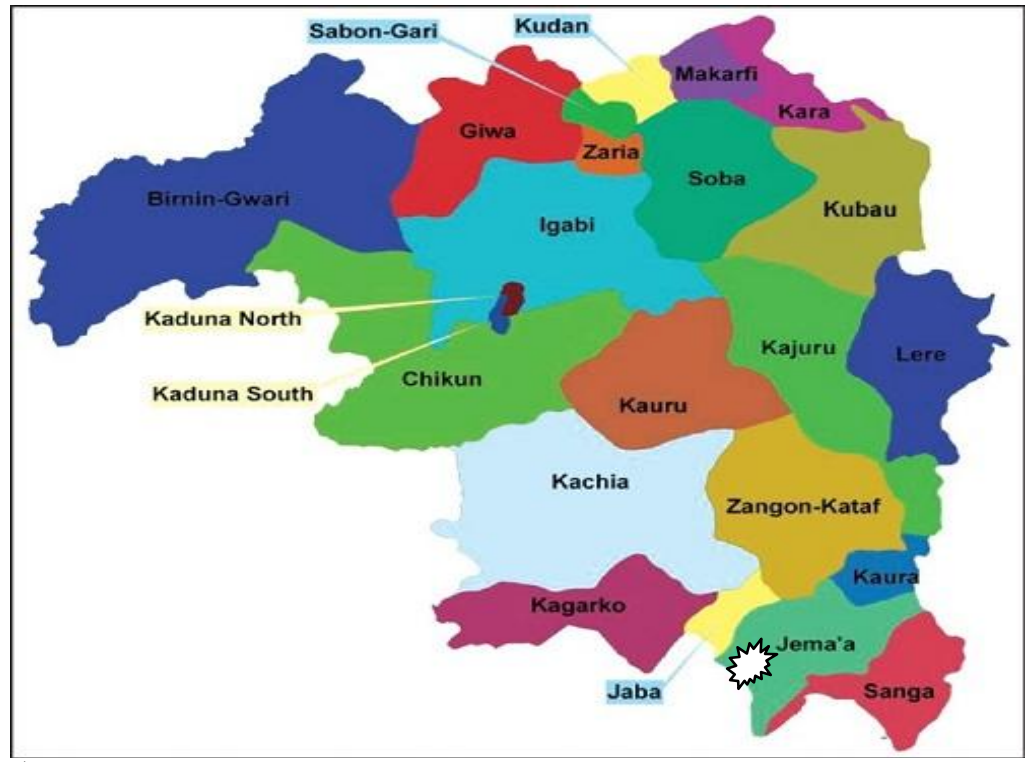

Study Area

Figure 1 Map of Kaduna State Showing the Location of the study Area

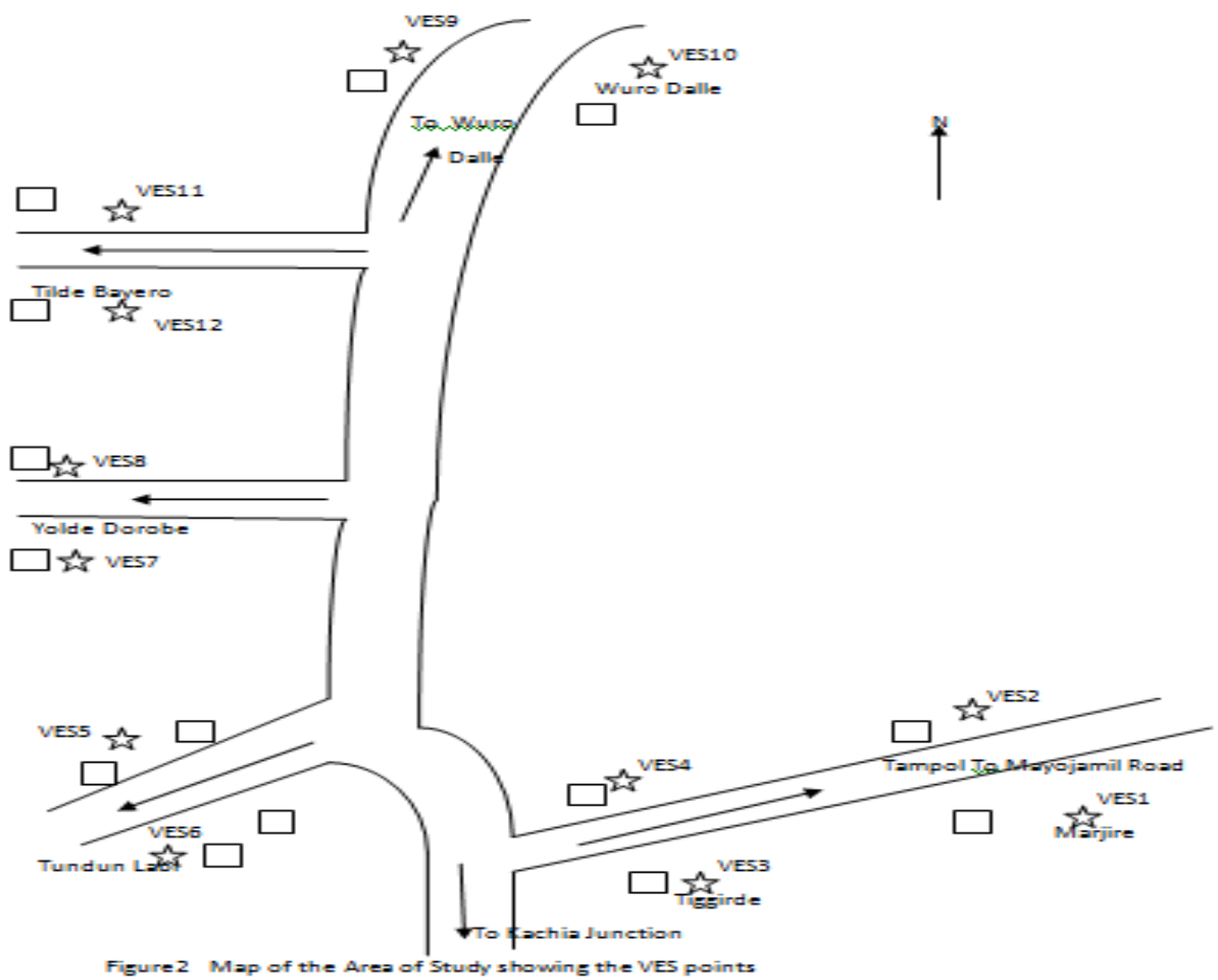




\section{Geology And Hydrogeology}

The study area consists mainly of the migmatite- Gneiss Complex which consists of migmatite, biotites and granitic gneiss. The migmatite gneiss complex represents reactivated metasedments which are characterized by a variety of structures and textures. Now, the basement complex lies in an extensive Pan-African mobile belt situated between the West African and Congo Cratons. It consists of a wide variety of metamorphic and igneous rocks and has been shown to be polycyclic with ages ranging from 2800M.a to 450M.a. The Pan-African event $(600 \pm 150 \mathrm{M}$.a) was the latest reactivation that affected the whole region (Fitches et al, 1985), and it caused regional metamorphism and deformation which imposed a generally N-S foliation trend and brought about the emplacement of granitoids. The basement complex can be subdivided into three major lithological units which are Migmatite-Gneiss complex; Older Granite and Schist Belt. The crystalline basement complex can thus be considered to compose mainly of metamorphic rocks. The major rock type in the area of study comprises of migmatite-gneiss complex that underlain most of the area. The metasedimentary series consists of undifferentiated schist, including gneiss, fine grained flaggy quartzite and pegmatites. These are metamorphosed sedimentary and metavolcanic rocks. The area is capped by laterites. The laterites are sometimes highly consolidated especially at the surface and weathered into lateritic nodules mixed with silty and sandy clays.

The storability and hydraulic conductivity of groundwater flow systems in the crystalline basement areas as in the area of study depend on the extent of development of secondary structural features such as the weathered overburden and fractures. These fractures tend to close with depth due to increasing weight of the overburden. In this area groundwater therefore occurs either in the weathered mantle or fractured systems of the unweathered or partly weathered bedrock or both as these two aquifer types mostly interconnected in places culminating in groundwater basins. Due to differential weathering, these groundwater basins are often localized in such a way that it becomes desirable for a geophysical investigation to be carried out prior to drilling to locate them as accurately as possible to avoid abortive wells. This is the justification for the investigations. The local hydrogeology at the premises investigated is characterized by shallow groundwater conditions as is evidenced by the presence of dug wells (about $6 \mathrm{~m}$ depth) reflecting encouraging potentials for groundwater development.

\section{Materials And Methods}

The Schlumberger array of resistivity method was employed for the sounding, using ABEM Terrameter SAS $300 \mathrm{~B}$ (powered by $12 \mathrm{~V}$ battery) in conjunction with electrodes, connecting wires, plugs, clips and hammer etc. The method usually gives optimal results for depth definition. The data are collected along the traverses at the various VES points. The principle of the resistivity method is that an electric current is passed into the ground through two outer electrodes, and the resulting potential difference (voltage drop) is measured across two inner electrodes, while the ratio of the potential difference to the current is displayed by the meter as a resistance. The electrodes are arranged in collinear pattern and symmetrically about a centre point which is the point of investigation. A geometric factor is calculated as a function of the electrode spacing and resistance readings multiplied by it to give an apparent resistivity value. The electrode spacing is progressively increased, keeping the centre point of the electrode array in fixed position.

\subsection{Results}

\section{Results And Discussion}

The VES interpretation results are presented in Figures 3 to 14, while the pseudo and resistivity sections across VES1 to VES 6 and across VES 7 to VES 12 are presented respectively in Figures 15 to 18. In addition, Table 2 shows the Geoelectric parameters deduced from the VES interpretation.

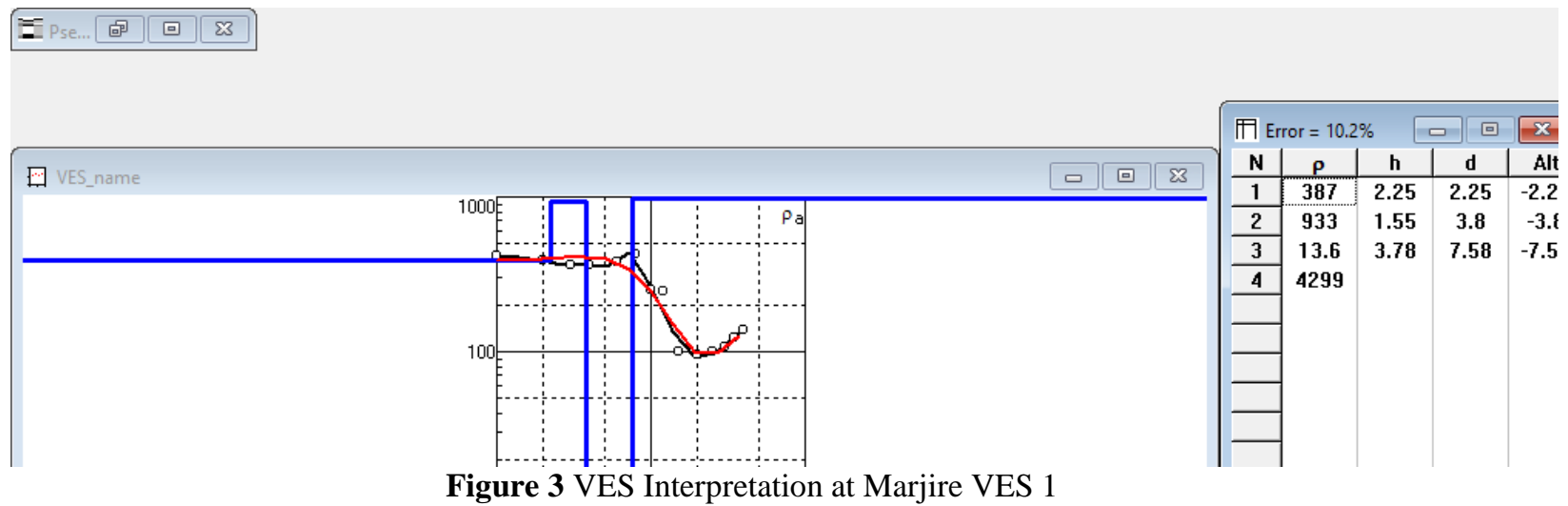

Figure 3 VES Interpretation at Marjire VES 1 

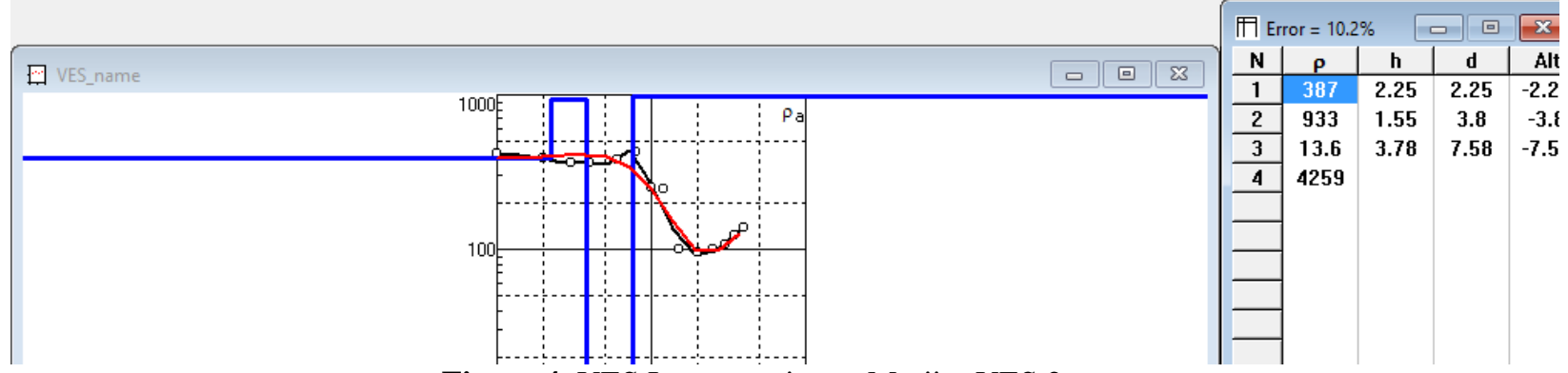

Figure 4 VES Interpretation at Marjire VES 2

\section{E- Pse... 國 $\quad$ 回 83}
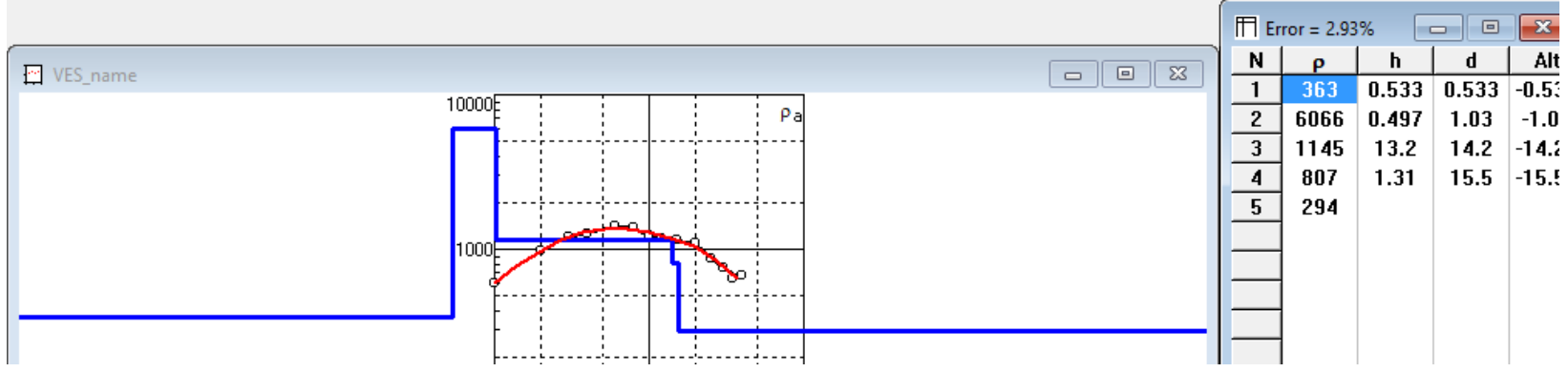

Figure 5 VES Interpretation at Tiggirde VES 3
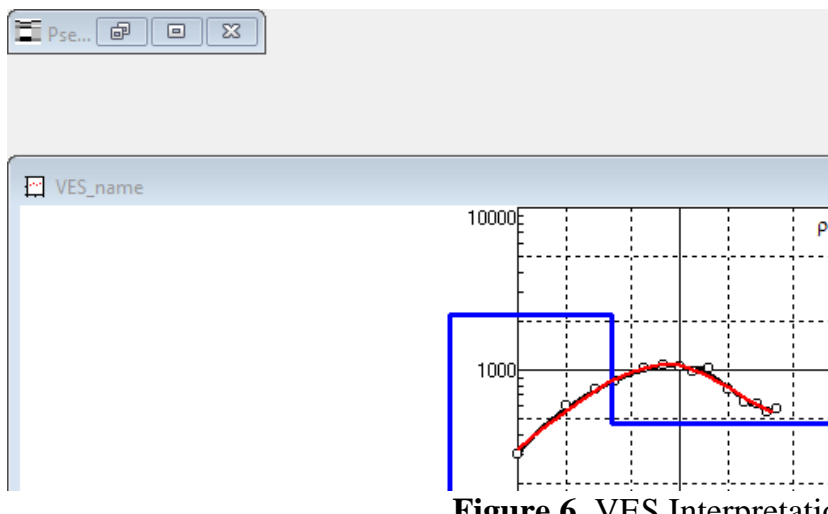

口 回 $\mathbb{2}_{3}$

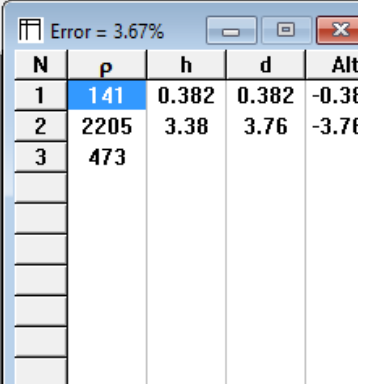

Figure 6 VES Interpretation at Tiggirde VES 4

\section{E- Pse... 回 $\square 83$}
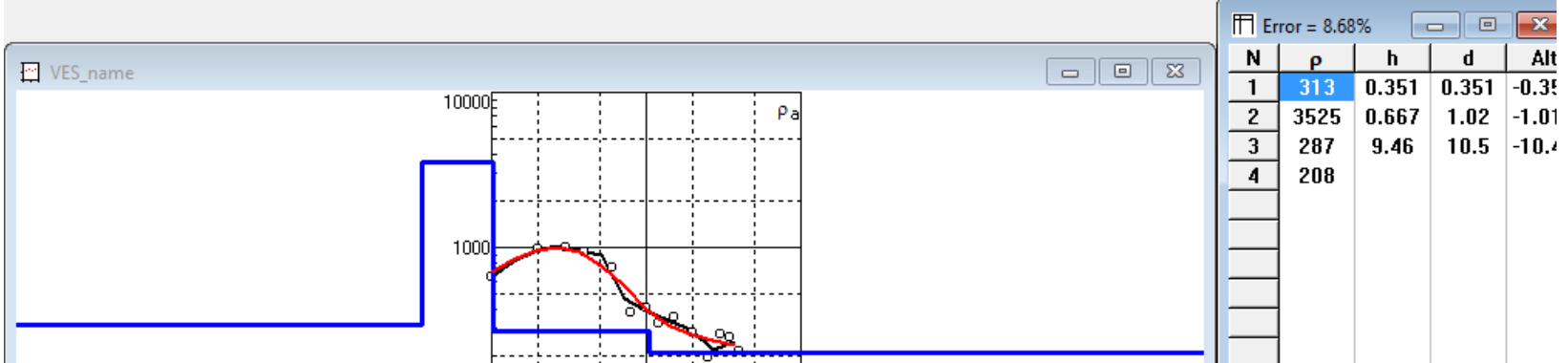

Figure 7 VES Interpretation at Tundunlabi VES 5 

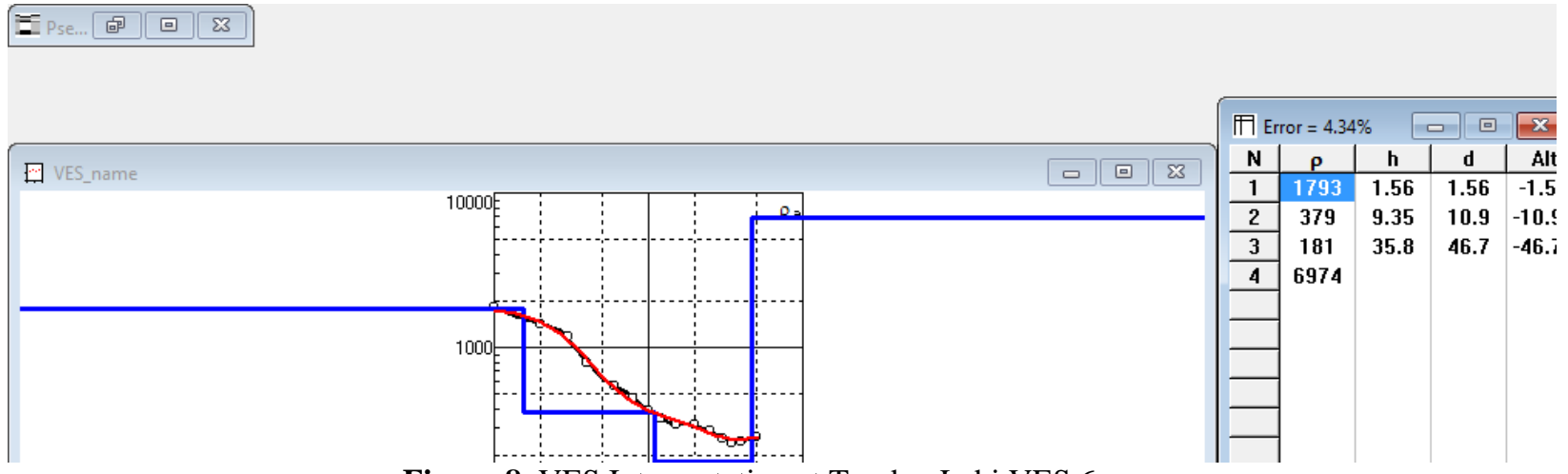

Figure 8 VES Interpretation at Tundun Labi VES 6
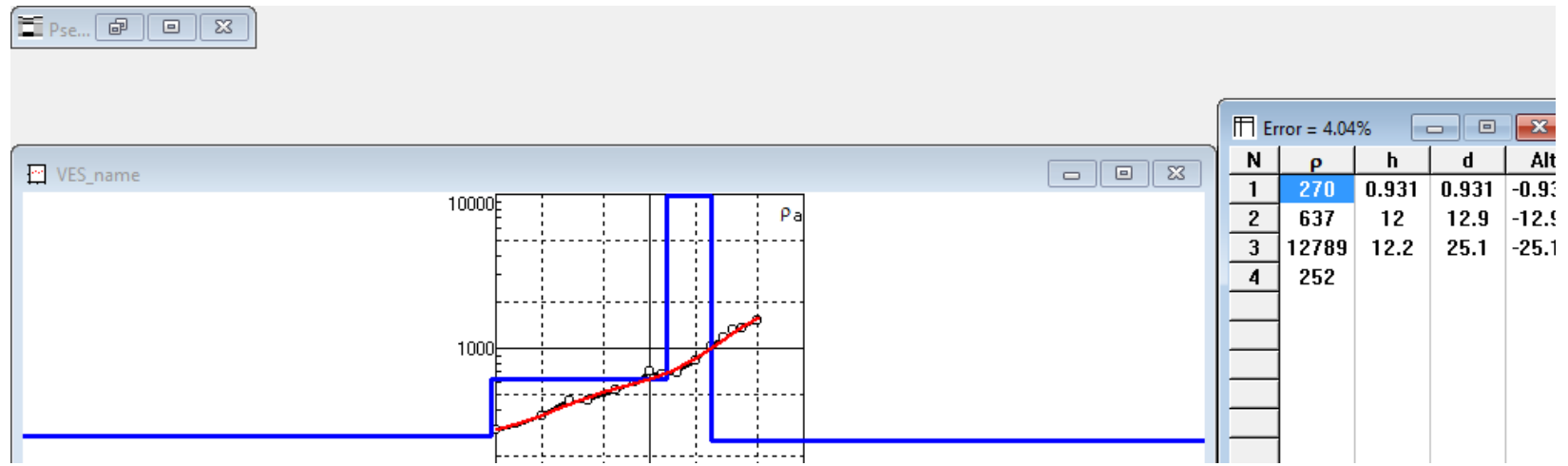

Figure 9 VES Interpretation at Yolde Dorobe VES 7
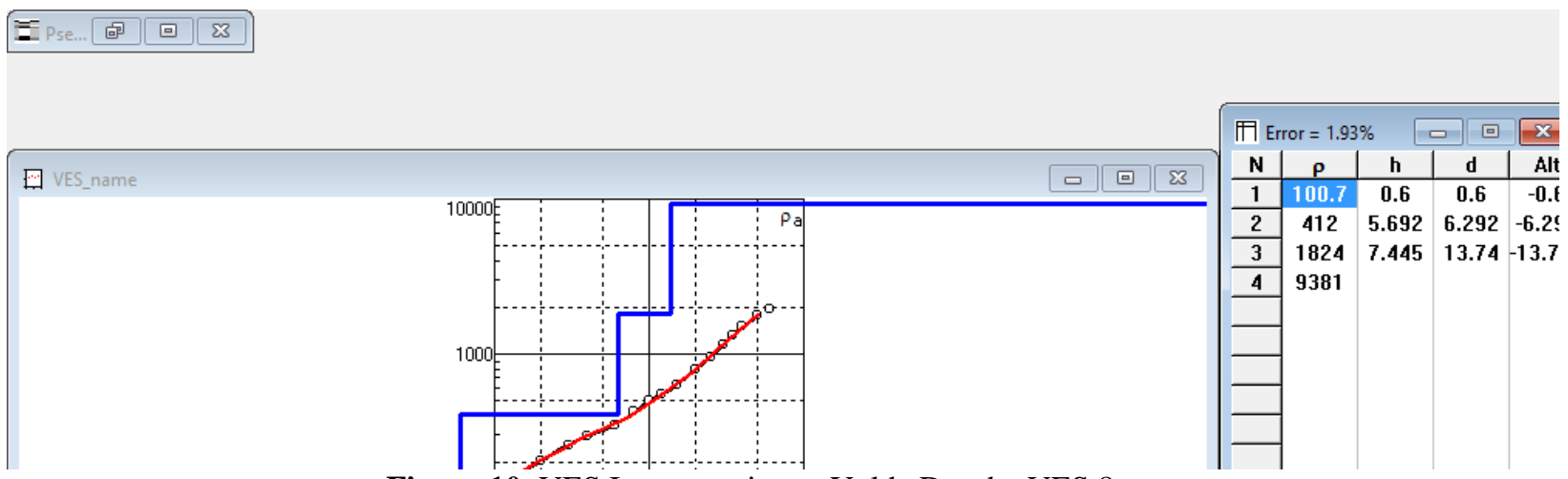

Figure 10 VES Interpretation at Yolde Dorobe VES 8
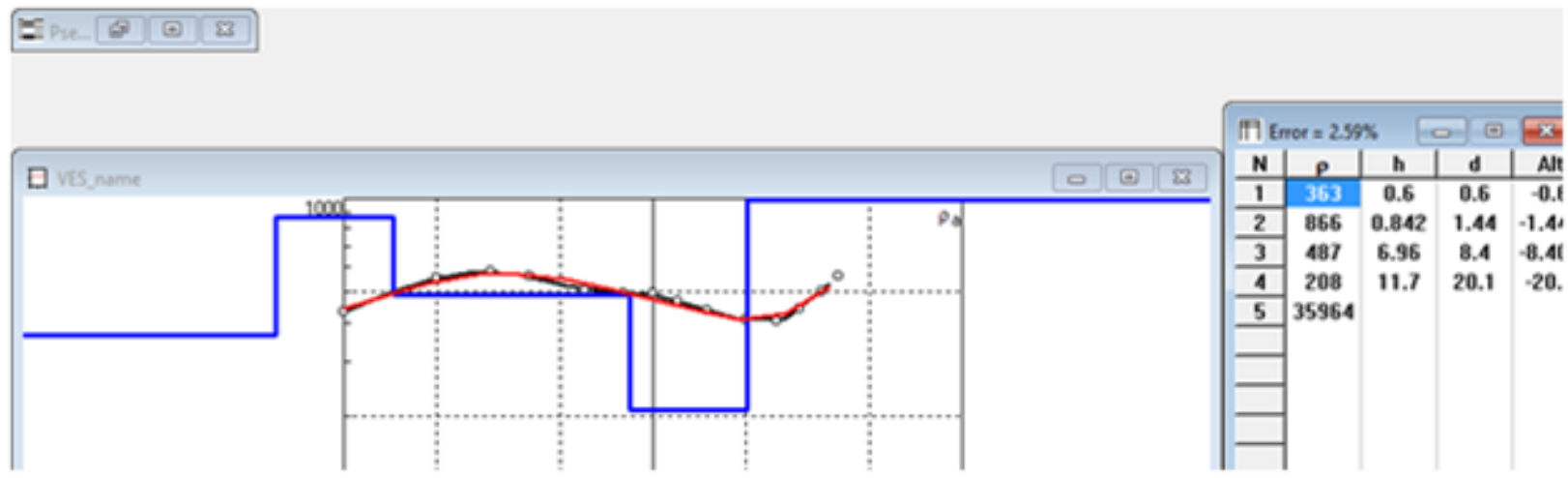

Figure 11 VES Interpretation at Wuro Dalle VES 9 


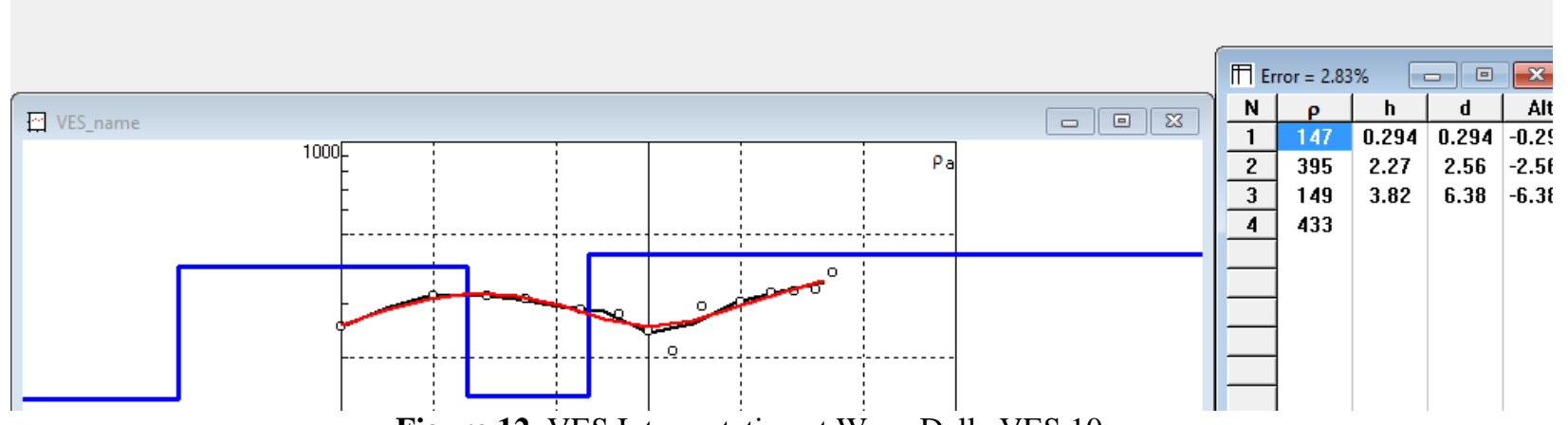

Figure 12 VES Interpretation at Wuro Dalle VES 10

\section{三 Pse... 回回 83}

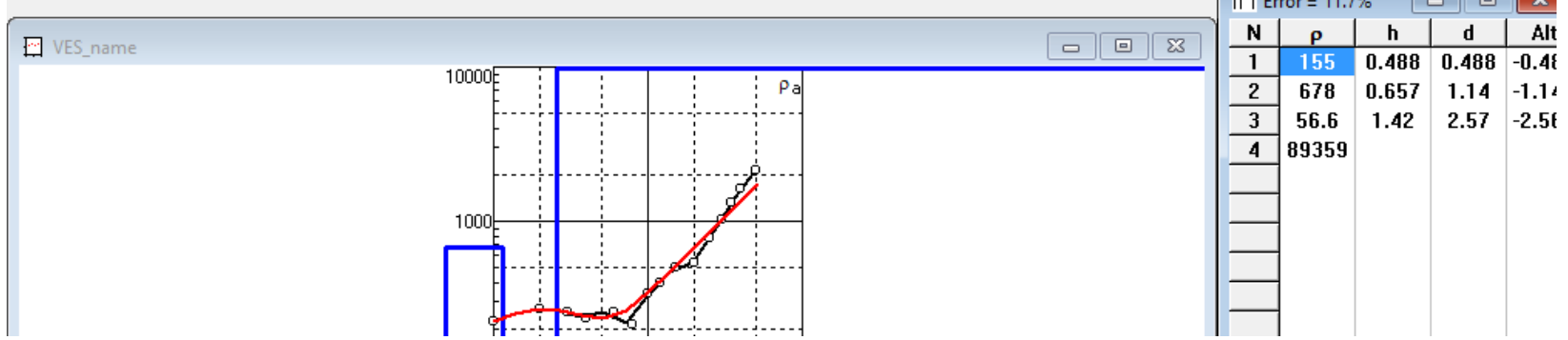

Figure 13 VES Interpretation at Yolde Dorobe VES 11
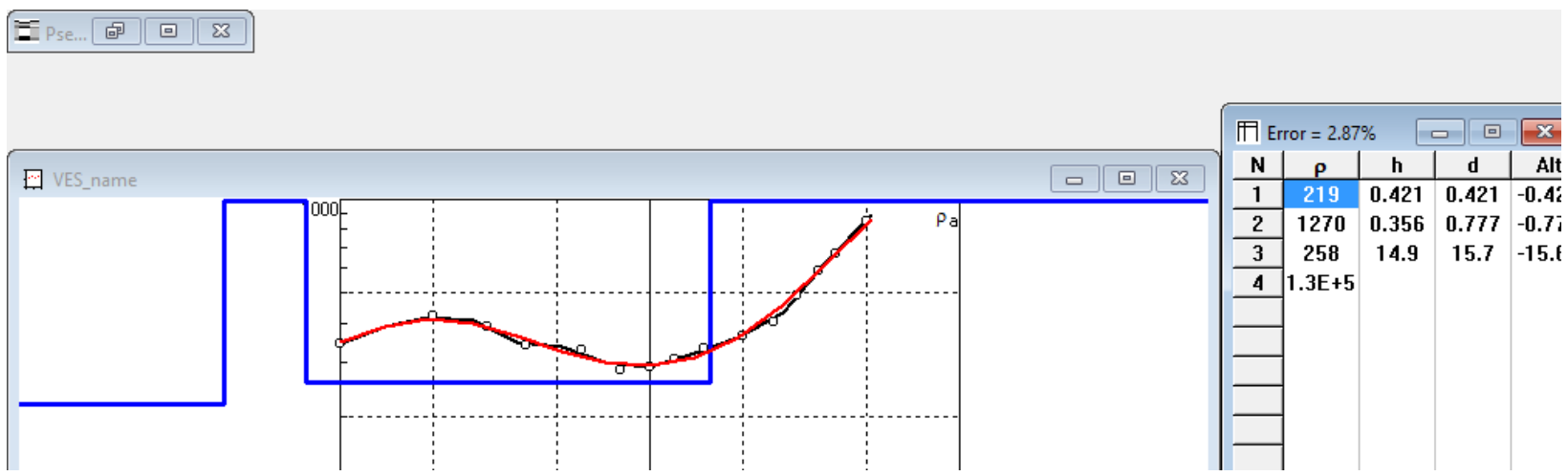

Figure 14 VES interpretation at Tilde Bayero VES 12

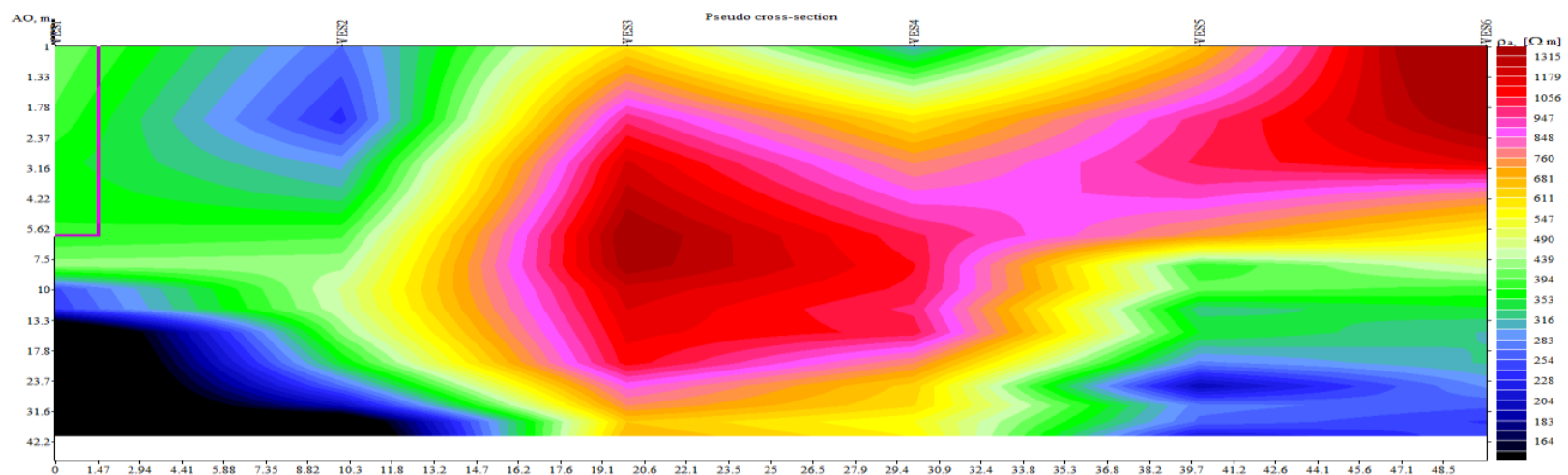

Figure 15 Psedosection Across VES 1 to VES 6 


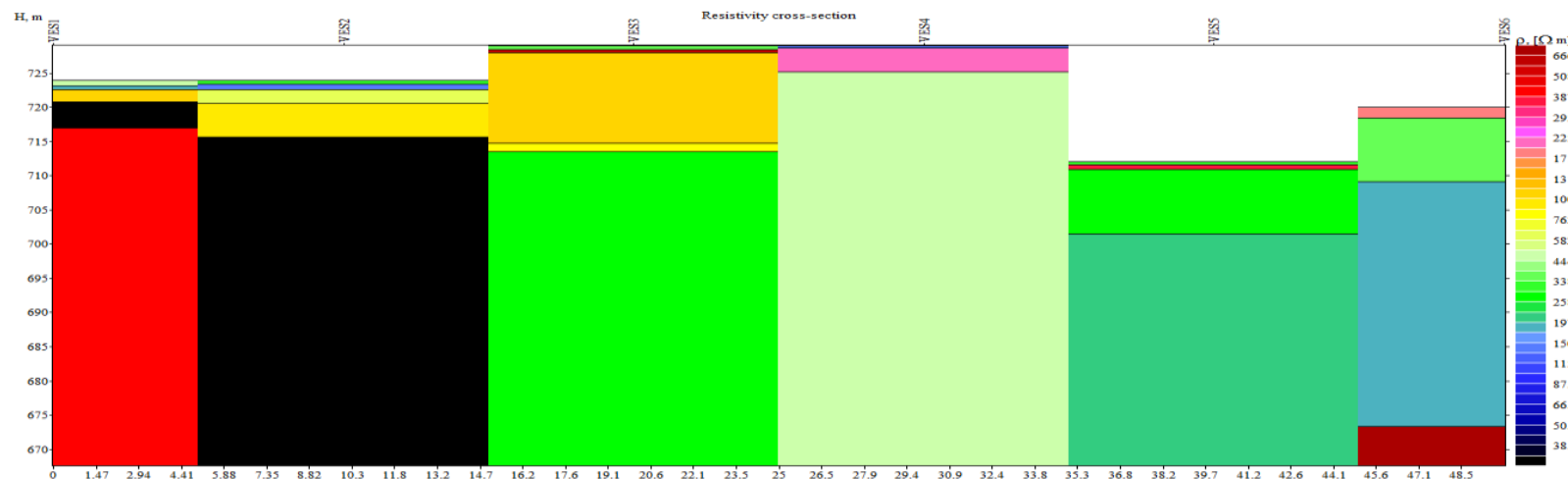

Figure 16 Resistivity Cross-Section Across VES 1 to VES 6

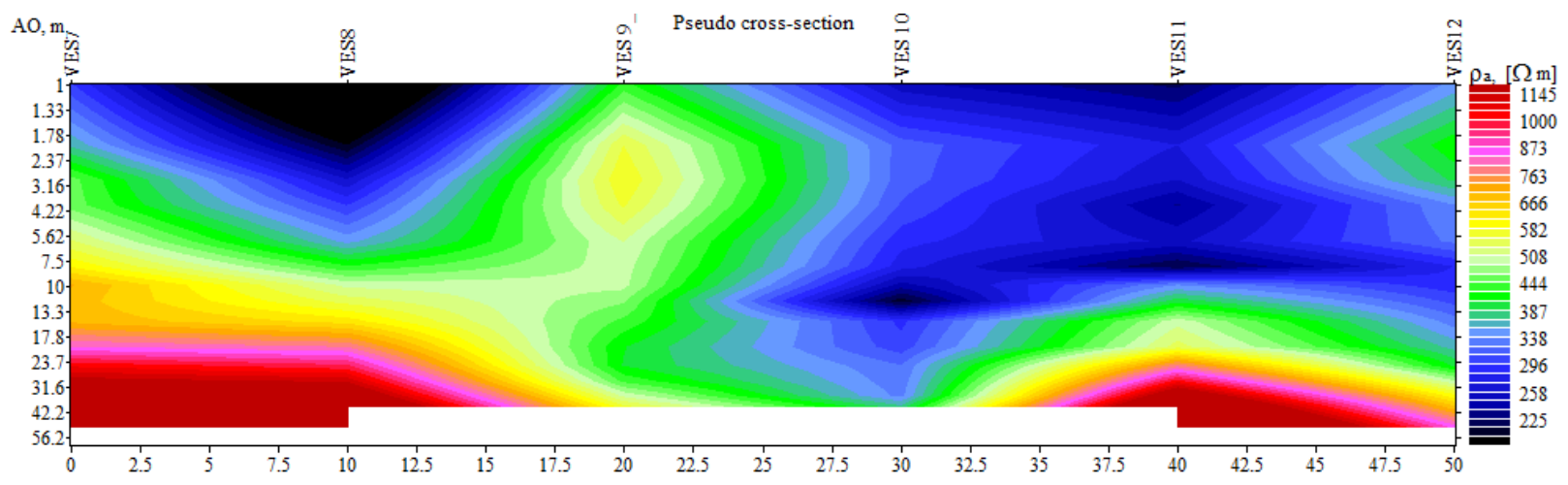

Figure 17 Psedosection Across VES 7 to VES 12

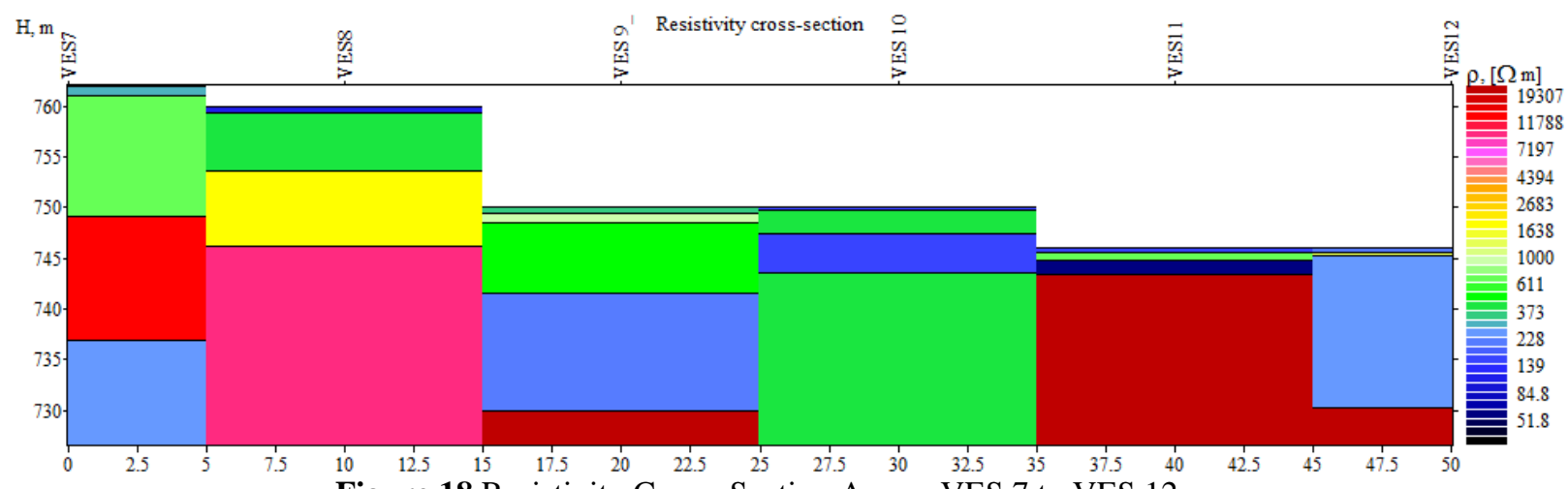

Figure 18 Resistivity Cross- Section Across VES 7 to VES 12

Table 2 Showing the Geoelectric Parameters at each VES points

\begin{tabular}{|l|l|l|l|l|l|l|}
\hline $\begin{array}{l}\text { Location and } \\
\text { VES No }\end{array}$ & $\begin{array}{l}\text { Overburden } \\
\text { thickness }(\mathrm{m})\end{array}$ & $\begin{array}{l}\text { Weathered Layer } \\
\text { thickness }(\mathrm{m})\end{array}$ & $\begin{array}{l}\text { Weathered Layer } \\
\text { Resistivity }(\Omega \mathrm{m})\end{array}$ & $\begin{array}{l}\text { Thickness of } \\
\text { fractured zone }\end{array}$ & $\begin{array}{l}\text { Number of } \\
\text { Layers }\end{array}$ & $\begin{array}{l}\text { Type of } \\
\text { Curve }\end{array}$ \\
\hline Marjire VES 1 & 7.58 & 3.78 & 13.6 & - & 4 & $\mathrm{KH}$ \\
\hline $\begin{array}{l}\text { Marjire } \\
\text { VES 2 }\end{array}$ & 7.03 & 3.88 & 13.9 & - & 4 & $\mathrm{KH}$ \\
\hline $\begin{array}{l}\text { Tiggirde } \\
\text { VES 3 }\end{array}$ & 0.533 & - & - & $\infty$ & 3 & $\mathrm{~K}$ \\
\hline $\begin{array}{l}\text { Tiggirde } \\
\text { VES 4 }\end{array}$ & 0.382 & - & - & $\infty$ & 3 & $\mathrm{~K}$ \\
\hline $\begin{array}{l}\text { Tundun Labi } \\
\text { VES 5 }\end{array}$ & 0.351 & - & - & $\infty$ & 4 & $\mathrm{KQ}$ \\
\hline $\begin{array}{l}\text { Tundun Labi } \\
\text { VES 6 }\end{array}$ & 46.7 & 9.35 & 379.0 & 35.8 & 4 & $\mathrm{QH}$ \\
\hline $\begin{array}{l}\text { Yolde Dorobe } \\
\text { VES7 }\end{array}$ & 12.9 & 12 & & & & \\
\hline $\begin{array}{l}\text { Yolde Dorobe } \\
\text { VES 8 }\end{array}$ & 6.29 & 5.69 & 637.0 & $\infty$ & 4 & $\mathrm{AK}$ \\
\hline
\end{tabular}


Geoelectrical Evaluation Of The Variation In The Spatial Distribution Of Aquifers In The Basement

\begin{tabular}{|l|l|l|l|l|l|l|}
\hline $\begin{array}{l}\text { Wuro Dalle VES } \\
9\end{array}$ & 20.1 & 6.96 & 487.0 & 11.7 & 5 & $\mathrm{KQH}$ \\
\hline $\begin{array}{l}\text { Wuro Dalle VES } \\
10\end{array}$ & 6.38 & 3.82 & 149.0 & $\infty$ & 4 & $\mathrm{KH}$ \\
\hline & & & & & & \\
\hline $\begin{array}{l}\text { Tilde Bayero } \\
\text { VES 11 }\end{array}$ & & & & & & \\
\hline $\begin{array}{l}\text { Tilde Bayero } \\
\text { VES 12 }\end{array}$ & & 1.57 & 56.6 & - & 4 & $\mathrm{KH}$ \\
\hline
\end{tabular}

\subsection{Discussion}

The VES results were initially interpreted manually on the field and then improved upon using the IPI2Win Resounding Interpretation Softwares whose results are presented in Figures 3 to 18 as field digitized curves, pseudo and resistivity sections. Deductions from the interpretation are as follows:

The VES interpretation shows typically 5 layer curve of the type KQH, i.e, $\rho_{1}<\rho_{2}>\rho_{3}>\rho_{4}<\rho_{5}$ at Wuro Dalle (VES 9); 4 layer curves of the type KH, i.e $\rho_{1}<\rho_{2}>\rho_{3}<\rho_{4}$ at Marjire, Wuro Dalle (VES 10) and Tilde Bayero ; 4 layer curve of the type KQ, i.e $\rho_{1}<\rho_{2}>\rho_{3}>\rho_{4}$ at Tundun Labi VES 5; 4 layer curve of the type QH, i.e $\rho_{1}>\rho_{2}>\rho_{3}<\rho_{4}$ at Tundun Labi VES 6; 4 layer curve of the type AK, i.e $\rho_{1}<\rho_{2}<\rho_{3}>\rho_{4}$ at Yolde Dorobe VES 7; 4 layer curve of the type AA, i.e $\rho_{1}<\rho_{2}<\rho_{3}<\rho_{4}$ at Yolde Dorobe VES 8. While the 3 layer curves are of the K type, i.e $\rho_{1}<\rho_{2}>\rho_{3}$, and are found at Tiggirde. The five layers correspond to five lithologic units which are; top lateritic soil, silty/ sandy clay, weathered basement, fractured basement and very fresh basement. While the four layers correspond to four lithological units, which are top soil, sandy clay zone, weathered basement and fresh but fractured basement. And the three layers correspond to three lithological units, which are top soil, more resistive sandy clay unit and fresh but fractured basement. Both the weathered basement (regolith) and the fractured zones at depths constitute the aquifers of interest. For Marjire, the depth to basement ranges between 7.03 and $7.58 \mathrm{~m}$. While the thickness of the weathered layer and corresponding resistivities range are $3.78-3.88 \mathrm{~m}$ and $13.6-13.9 \Omega \mathrm{m}$ respectively. Here the fractured zone is absent.

For Tiggirde, the depth to basement ranges between 0.382 and $0.533 \mathrm{~m}$ and as such very shallow as evident in the well the villagers had to abandon as they met crystalline rocks at a shallow depth of about $2 \mathrm{~m}$. The relatively low resistivity values of layer 3 (basement) suggests fractured zones at depths. For Tundun Labi, the depth to basement ranges from 0 to $0.351 \mathrm{~m}$, this can be justified by the presence of basement outcrops found in the vicinity of the area of survey. The relatively low resistivity values of layers 3 and 4 in VES 5 and layers 2 and 3 in VES 6 indicate fractured basement. The depth to'very' fresh (unfractured) basement in VES 6 is $46.7 \mathrm{~m}$, leaving about $45.15 \mathrm{~m}$ as thickness of the fractured zone. While the thickness of the weathered zone in VES 5 is not defined.

At Yolde Dorobe, the overburden thickness ranges from 6.29 to $12.9 \mathrm{~m}$. While the thickness of the weathered layer and corresponding resistivities range are $5.69-12.0 \mathrm{~m}$ and $412.0-637.0 \Omega \mathrm{m}$ respectively. The thicknesss of the fractured zone ranges from $7.445 \mathrm{~m}$ to $\infty$. For Wuro Dalle, depth to basement ranges between 6.38 and $20.1 \mathrm{~m}$. While the thickness of the weathered layer and corresponding resistivities range are $3.82-6.96 \mathrm{~m}$ and $149.0-487.0 \Omega \mathrm{m}$ respectively. The thicknesss of the fractured zone ranges from $11.7 \mathrm{~m}$ to $\infty$

Finally, at Tilde Bayero, the depth to basement is between 0.421 and $2.57 \mathrm{~m}$. In VES 11, the thickness of the weathered basement is about $1.42 \mathrm{~m}$ with a corresponding resistivity of $56.6 \Omega \mathrm{m}$. No fracture is indicated here. The thickness of the overburden in VES 12 is $0.421 \mathrm{~m}$, implying negligible weathered basement. Although there is a well developed fracture zone with a thickness of $14.9 \mathrm{~m}$

Considering Pseudosection across VES1- VES6 (Figure 15), the high groundwater potential is found from VES1 to just a little beyond VES2, with a resistivity range of between 180 and $400 \Omega m$ at shallow depth ranging from 0 to about $15 \mathrm{~m}$. While the resistivity values decreases further (i.e less than $200 \Omega \mathrm{m}$ ) from $20 \mathrm{~m}$ depth. The area just a little beyond VES2 to VES4 is completely a high resistive zone up to 20m depth as the resistivity values range from about 500 to $>1000 \Omega \mathrm{m}$, although, the resistivity values diminish at deeper depth and this may be due to fractures in the basement. Between VES 4 and VES6, the high resistivity range is found at shallow depth up to $5 \mathrm{~m}$, while the low resistivity range of $180-400 \Omega \mathrm{m}$ is found at deeper depth. Also, Figure 16 shows the Pseudosection across VES7-VES12. Here, between VES7 and VES8, low resistivity values of about $10-500 \Omega \mathrm{m}$ is found at shallow depth up to $5 \mathrm{~m}$. While the high resistivity range ( 500 to $>1000 \Omega \mathrm{m}$ ) is found at deeper depth $(5$ to $>50 \mathrm{~m})$. At the vicinity of VES 9 , the resistivity values generally range from 400 to $650 \Omega \mathrm{m}$. And just beyond VES 9 to VES 12, the resistivity values range from about 300 to $400 \Omega \mathrm{m}$ up to a depth of $20 \mathrm{~m}$. Although, the resistivity values becomes higher at deeper depth at a range between 500 and $>1000 \Omega \mathrm{m}$. 


\section{Conclusion And Recommendation}

The VES interpretation has been carried out to investigate the variation in the spatial distribution of aquifers in the area of study. And from the results, it has been shown that there is considerable variability in extent, type, thickness, water content, permeability and resistivity of the aquifers within the study area which can be said to be less than $5 \mathrm{~km}^{2}$ (See Table 2). This is quite unlike what is expected to be found in a sedimentary environment where aquifer properties are constant over a large area. For water borehole development in the area of study, the groundwater potential in the area of study can be considered to be medium and the following VES points are recommended for drilling with respect to the VES interpretation; VES1, VES2, VES5, VES6, VES9, VES10 and VES12.

\section{References}

[1] Adanu, E.A (1989) "Hydrogeology of the Basement Complex Terrain in the Zaria - Kaduna Area". Ph.D Thesis FU TFH TU, Berlin. P75

[2] Adanu, E.A (1994) "Groundwater Development and Management in the Basement Complex Terrain in Zaria-Kaduna Area". Water Resources 4(1 and 2), 64-68

[3] Ademilua, O.L; Ojo, F.O; Eluwole, A.B and Ademilua, O.B (2014) "Geophysical Survey for Groundwater Resources. Appraisal in a Basement Complex Terrain for Agricultural Purposes. Case Study of ABUAD Teaching and Research Farm, Ado Ekiti, Southwest Nigeria". Global Journal of Science Frontier Research. H Environmental and Earth Science. Vol. 14 Issue 5 Version 1.0, p1-14

[4] Afuwai G.C (2013) "The Variation in the Depth of Overburden at different VES points within Samaru Using DC Resistivity Technique". Academic Journal of Interdisciplinary Studies. 2(12)

[5] Afuwai, G.C; Lawal, K.M and Aminu, A.L "Investigation of Groundwater Potential at Samaru College of Agriculture", ABU, Zaria, Nigeria

[6] Alagbe, S.A (1987) "Hydrogeology of the River Kangimi Catchment Area, Kaduna State, Unpub. M.Sc Thesis. Dep. GEOl. ABU, Zaria, Nigeria, p168

[7] Anudu, G.K; Onwuemesi, A.G; Ajaegwu, N.E; Onuha, L.N and Omali, A.O (2008) "Electrical Resistivity Investigation for Groundwater in the Basement Complex Terrain: A Case Study of Idi Ayunre and its Environs, Oyo State, South western Nigeria. Natural and Applied Sciences Journal, 9(2), p1-12

[8] Asiwaju- Bello, Y.A and Ololade, J.O (2013) "Groundwater Potential of Basement Aquifers in Part of Southwest Nigeria. American Internatinal Journal of Contempoary Research, 3(3), p124-141

[9] Bala, E.A; Eduvie, O.M and Jolly, B (2011) "Borehole Depth and Regolith Aquifer Hydraulic Characteristics of Bedrock types in Kano Area, Northern Nigeria. African Journal of Environmental Science and technology. 5(3), p228-237

[10] Barker, R; Rao, T.V; Thangarajam, M (2001) "Delineation of Contaminant Zone through Electrical Imaging Technique" Curr. Scien. 81(3), p277-283

[11] Dan Hassan, M.A and Olorunfemi, M.O (1999) "Hydrogeophysical Investigation of a Basement Terrain in the North Central part of Kaduna State, Nigeria. Journal of Mining and Geology 35(20, p189-206

[12] Fitches , W.R; Ajibade, A.C; Egbuniwe, I.G; Holt, R.W and Wright, J.B (1985) “ Late Protezoic Schist Belts and Plutonism in Northwestern Nigeria. J. Geol. Soc. London. 142. p319-337

[13] Ismail, A.Y and Yola, A.L (2012) "Geoelectric Investigation of Groundwater Potential of Dawakin Tofa Local Government Area of Kano State, Nigeria. American International Journal of Contempoary Research, 2(9)

[14] Jeff, D (2006) "Forum for Groundwater" http//www.wternet.co.zalgroundwater

[15] National Water Resources Institute, 2012. Groundwater Investigation Techniques. RWSSC Course 1, (Kaduna Centre).

[16] Keary P and Brooks M (1984). An Introduction to Geophysical Exploration. Blackwell.

[17] Kollert R, 1969. "Ground water Exploration by the electrical resistivity method" Atlas Copco ABEM Geophysics and Electronics. Geophysical Memorand 3/6

[18] Mogaji, K.A; Olayanju, G.M and Oladapo, M.I (2011) "Geophysical Evaluation of Rock Type Impact on Aquifer Characterization in the Basement Complex Areas of Ondo State, Southwestern Nigeria. Geoelectric Assessment and Geographic Information System (GIS) Approach. International Journal of Water Resources and Environmental Engineering, 3(4), p77-86

[19] Mohammed, I (1984) "Hydraulic Properties of the Basement Complex and Chad Formation Aquifers of Kano State based on TestPumping of selected boreholes. M.Sc Thesis, Dept. Geol. ABU, Zaria, Nigeria

[20] Salpathy, B.N and Kanungo, B.N (1976) "Groundwater Exploration in Hard Rock Terrain. A Case Study. Geophys. Prospecting, 24(4), p724-763

[21] Steeples (2001)

[22] Telford, W; Geldart L.P and Sheriff R.E, 1990. Applied Geophysics, Cambridge University Press, Cambridge.

[23] Uma, K.O and Kehinde, M.O (1994) "Potentials of Regolith Aquifers in Relation to Water Supplies to Rural Communities. A Case Study from Parts of Northern Nigeria, Journal of Mining Geology, 30, p97-109

\footnotetext{
Omotayo Kayode. "Geoelectrical Evaluation Of The Variation In The Spatial Distribution Of Aquifers In

I The Basement Complex - A Case Study Of Laduga Community, Kaduna State, North Central, Nigeria."

IOSR Journal of Applied Geology and Geophysics (IOSR-JAGG) 5.4 (2017): 34-44.
} 